\begin{tabular}{|l} 
JOURNAL OF EMPOWERMENT \\
VOL. 2, No. 2, Desember 2021, h. 270-275 \\
ISSN 2580-0620 (Print) \\
ISSN 2597-9809 (Online) \\
Available Online at https://jurnal.unsur.ac.id/index.php/JE \\
\hline \hline
\end{tabular}

\title{
PEMBERDAYAAN KELOMPOK BELAJAR SISWA DALAM EDUKASI PATUH
} KESEHATAN

\section{EMPOWERMENT OF STUDENT LEARNING GROUP IN HEALTH COMPLIANCE EDUCATION}

\author{
1Naurotul 'Abiidah, ${ }^{2 S}$ ri Anugrah Natalina \\ 12Institut Agama Islam Negeri Kediri \\ idanaura3@gmail.com, anugrah.sujadmiko@yahoo.com
}

\begin{tabular}{|l|l|l|} 
Masuk: 27 Agustus 2021 & Penerimaan: 04 Desember 2021 & Publikasi: 31 Desember 2021 \\
\hline
\end{tabular}

\begin{abstract}
ABSTRAK
Pemeritah mewajibkan mematuhi protokol kesehatan setiap melakukan aktivitas di luar rumah. Meningkatnya angka positif COVID-19 berdampak pada pembatasan kegiatan yang dilakukan di luar rumah seperti bekerja dan sekolah. COVID-19 merupakan penyakit dengan proses penularan yang cepat dengan masa inkubasi maksimal 14 hari. Tindakan preventif perlu dilakukan untuk menjaga diri tetap sehat dan tidak terinfeksi virus tersebut. Minimnya sosialiasi dalam masyarakat menjadikan faktor utama bertambahnya kasus positif COVID-19 di Indonesia. Ketidakpatuhan masyarakat dalam menerapkan protokol kesehatan merupakan hambatan bagi Indonesia untuk mengurangi kasus positif COVID-19. Pemerintah dan masyarakat harus berialan selaras untuk mewujudkan tujuan tersebut. Salah satunya kegiatan pemberdayaan yang dilakukan oleh mahasiswa KKN IAIN Kediri yang memberikan edukasi oatu kesehatan kepada anak-anak di Desa Bulu Kecamatan Semen Kabupaten Kediri.
\end{abstract}

Kata Kunci : Belajar; Edukasi; Pemberdayaan; Siswa.

\begin{abstract}
The government requires to comply with health protocols everytime doing activities outside the home. The increasing positive number of COVID-19 has an impact on limiting activities carried out outside the home such as work and school. COVID-19 is a disease with a rapid transmission process with a maximum incubation period of 14 days. Preventive measures need to be taken to keep yourself healthy and not infected with the virus. The lack of socialization in the community is the main factor for the increase in positive cases of COVID-19 in Indonesia. Public non-compliance in implementing health protocols is an obstacle for Indonesia to reduce positive cases of COVID-19. The government and society must work in harmony to achieve this goal. One of them is an empowerment activity carried out by KKN IAIN Kediri students who provide health or education to children in Bulu Village, Semen District, Kediri Regency.
\end{abstract}

\section{Keywords $\quad:$ Learn; Education; Empowerment; Student.}

\section{A. PENDAHULUAN}

Masa pandemik telah berjalan selama kurang lebih satu tahun setengah dengan awal kemunculan pada Desember 2019 di Wuhan, China. Pandemi ini disebabkan oleh penyakit COVID-19 yang menyebarluas di dunia termasuk Indonesia. Penularan COVID-19 sangat cepat dengan virus penginfeksinya bernama Severe Acute Respiratory Syndrome Coronavirus 2 (SARS-COV-2). Gejala-gejala umum yang sering terjadi karena terinfeksi virus ini adalah gejala pernapasan akut seperti demam, batuk dan sesak napas. Masa inkubasi dari virus ini bisa mencapai 
5-6 hari dengan maksimal 14 hari. Kasus berat COVID-19 adalah pasien terjangkit pneumonia, aindrom pernapasan akut, bahkan bisa terkena gagal ginjal (Rosmita \& Setyorini, 2021). Dengan masa inkubasi sedemikian rupa yang telah disebutkan di awal, jika penularan virus ini tergolong cepat, maka berpotensi menjatuhkan banyak pasien positif terinfeksi COVID-19.

Sejak virus corona masuk ke Indonesia pertama kali, angka penularan semakin naik begitu juga dengan kasus pasien positif juga meningkat. Per 22 Agustus 2021, tercatat 125.949 pasien COVID-19 terdaftar di tower 4, 5, 6 dan 7 RSD Wisma Atlet Kemayoran. Jumlah pasien yang keluar karena telah dinyatakan sembuh, rujuk ke rumah sakit lain ataupun meninggal sejumlah total 124.633 orang (Embu, 2021). Peningkatan jumlah kasus pasien positif COVID-19 diikuti dengan meningkatnya jumlah pasien sembuh. Faktor penyebab terbesar meningkatnya angka pasien positif COVID-19 di Indonesia adalah tidak patuhnya masyarakat terhadap protokol kesehatan yang diterapkan oleh pemerintah. Mulai dari $3 M$ yaitu mencuci tangan, memakai masker, dan menjaga jarak sampai akhirnya menjadi $5 \mathrm{M}$ dengan tambahan protokol untuk mengurangi mobilitas dan menjauhi kerumunan (Sukmana, 2021).

Dari awal ketika COVID-19 mulai menginfeksi masyarakat di Indonesia, pemerintah telah menerapkan kebijakan-kebijakan yang dianggap dapat meminimalisir penularan virus tersebut. Dimulai dengan social distancing, PSBB dan PPKM Mikro. PPKM Mikro merupakan Pemberlakuan Pembatasan Kegiatan Masyarakat yang berupa pembatasan aktivitas dari masyarakat dengan berdampak ditutupnya fasilitas umum seperti mall dan tempat wisata. Fasilitas umum yang masih menjadi prioritas masyarakat tidak ditutup, namun dibatas jumlah pengunjung per hari. Penyekatan antar kota juga dilakukan dari misi PPKM Mikro. Bukti bahwa masyarakat telah vaksin berguna untuk melewati PPKM ketika terjadi sesuatu yang mendesak. Tujuan dari pemberlakuan peraturan PPKM Mikro adalah mengurangi penularan COVID-19 sampai pada tingkat desa atau kelurahan dan mengupayakan peningkatan perekonomian masyarakat Indonesia secara bertahap (SK Mendagri No. 41 Tahun 2020; SK Menteri Perhubungan No. 18 Tahun 2020) (Napitu et al., 2021).

Dalam upaya untuk mematuhi protokol kesehatan dan anjuran vaksin, perlu sosialisasi yang cukup untuk masyarakat agar memahami sepenuhnya. Potensi untuk melakukan juga semakin besar ketika anjuran tersebut diberikan secara berkala. Sosialisasi bisa dilakukan oleh siapa saja yang telah paham betul mengenai protokol kesehatan. Salah satunya oleh mahasiswa KKN IAIN Kediri yang memberikan sosialisasi dan edukasi patuh kesehatan di Desa Bulu Kecamatan Semen. Penularan COVID-19 di desa atau tempat yang cakupannya lebih luas tidak terkontrol, apalagi ketika tidak mematuhi protokol kesehatan yang ada. Untuk meminimalisir penularan maka dibutuhkan pemahaman dari masyarakat sekitar khususnya masyarakat Desa Buku Kecamatan Semen dengan kegiatan pemberdayaan pemberian edukasi.

\section{B. METODE}

Metode pengabdian yang digunakan dalam hal ini adalah metode $A B C D$ (Hikmah et al., 2021). Prinsip-prinsip pengembangan masyarakat berbasis asset ( $A B C D)$ yang dijelaskan di bab ini yaitu (1) Setengah Terisi Lebih Berarti (Half full and half empty), dimana program pengabdian masyarakat berbasis aset adalah merubah cara pandang komunitas terhadap dirinya. Tidak hanya terpaku pada kekurangan dan masalah yang dimiliki. Tetapi memberikan perhatian kepada apa yang dipunyai dan apa yang dapat dilakukan, (2) Semua punya potensi (No 
body has nothing), tidak ada alasan bagi setiap anggota komunitas untuk tidak berkontribusi nyata terhadap perubahan lebih baik. (3) Partisipasi (Participation), peran serta seseorang atau kelompok masyarakat dalam proses pembangunan baik dalam bentuk pernyataan maupun dalam bentuk kegiatan dengan memberi masukan pikiran, tenaga, waktu, keahlian, modal dan atau materi, serta ikut memanfaatkan dan menikmati hasilhasil pembangunan. (4) Kemitraan (Partnership), upaya melibatkan berbagai komponen baik sektor, kelompok masyarakat, lembaga pemerintah atau non-pemerintah untuk bekerja sama mencapai tujuan bersama berdasarkan atas kesepakatan, prinsip, dan peran masing-masing (5) Penyimpangan positif (Positive Deviance), memungkinkan sebuah komunitas atau organisasi untuk mengidentifikasi dan memperkuat praktek-praktek tersebut, mengukur hasil, dan berbagi strategi sukses mereka dengan lain. (6) Berasal dari dalam masyarakat (Endogenous), pembangunan yang berdasar dari dalam konteks atau komunitas tertentu atau pembangunan yang dikembangkan dari dalam masyarakat. (7) Mengarah pada sumber energy (Heliotropic), Komunitas juga seharusnya mengenali peluang-peluang sumber energi lain yang mampu memberikan penyegaran kekuatan baru dalam proses pengembangan. Metode $A B C D$ digunakan untuk pengabdian yang memanfaatkan asset sebagai langkah awal untuk memulai kegiatannya. Dalam hal ini, pemberdayaan melalui kegiatan edukasi kepada masyarakat sangat relevan dengan metode $A B C D$ untuk memanfaatkan dan mengenali asset yang dimiliki serta untuk dikembangkan.

\section{HASIL ATAU PEMBAHASAN}

Desa Bulu merupakan salah satu desa yang berada dalam Kecamatan Semen Kabupaten Kediri. Desa tersebut dijadikan sasaran kegiatan pengabdian mahasiswa KKN IAIN Kediri dengan subjek anak-anak SD dan SMP. Sosialisasi tentang bahaya COVID-19 perlu disapaikan diikuti dengan edukasi penerapan protokol kesehatan di setiap kegiatan yang dilakukan di luar rumah. Apalagi per 2021, varian virus corona penyebab COVID-19 semakin banyak dengan penularan yang sanagt cepat. Anak-anak berpotensi menjadi pasien positif jika tidak menerapkan protokol kesehatan. Mengingat vaksin hanya diberikan kepada seseorang yang telah berumur 18 tahun keatas, maka anak-anak belum termasuk kategori usi siap vaksin. Tindakan preventif dilakukan untuk meminimalisir penularan COVID-19 adalah dengan langkah-langkah utama seperti penggunaan masker; menutup mulut dan hidung saat bersin ataupun batuk; mencuci tangan secara teratur dengan sabun atau desinfeksi dengan pembersih tangan yang mengandung setidaknya $60 \%$ alkohol; menghindari kontak dengan orang yang terinfeksi; menjaga jarak dari orangorang; dan menahan diri dari menyentuh mata, hidung, dan mulut dengan tangan yang tidak dicuci (Sudiadnyani et al., 2021).

Kegiatan pemberdayaan melalui edukasi anak-anak SD dan SMP Desa Bulu Kecamatan Semen Kabupaten Kediri berjalan dengan lancar. Kegiatan dilakukan dengan waktu tiga kali seminggu. Sasaran dari kegiatan ini adalah 15 anak yang bertempat di salah satu mushola di Desa Bulu. 


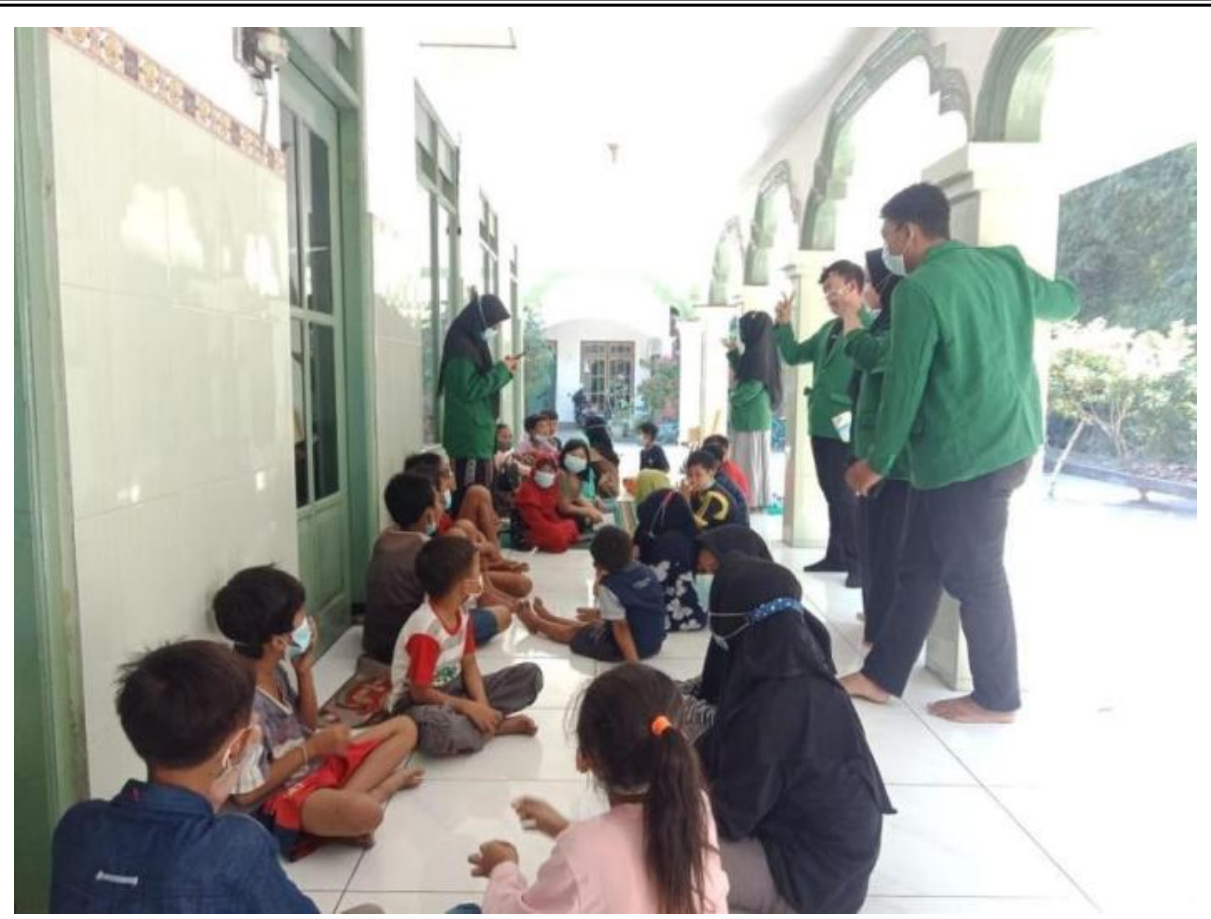

Gambar 1. Perkenalan mahasiswa KKN IAIN Kediri

Pemberdayaan yang dilakukan adalah edukasi pentingnya memakai masker pada anakanak saat pandemic COVID-19. Cara memakai masker yang baik juga disosialisasikan oleh mahasiswa KKN IAIN Kediri. langkah-langkah mencuci tangan yang benar harus disampaikan untuk mencegah penularan COVID-19 yang terus meningkat kasusnya di Indonesia, khususnya di Kabupaten Kediri.

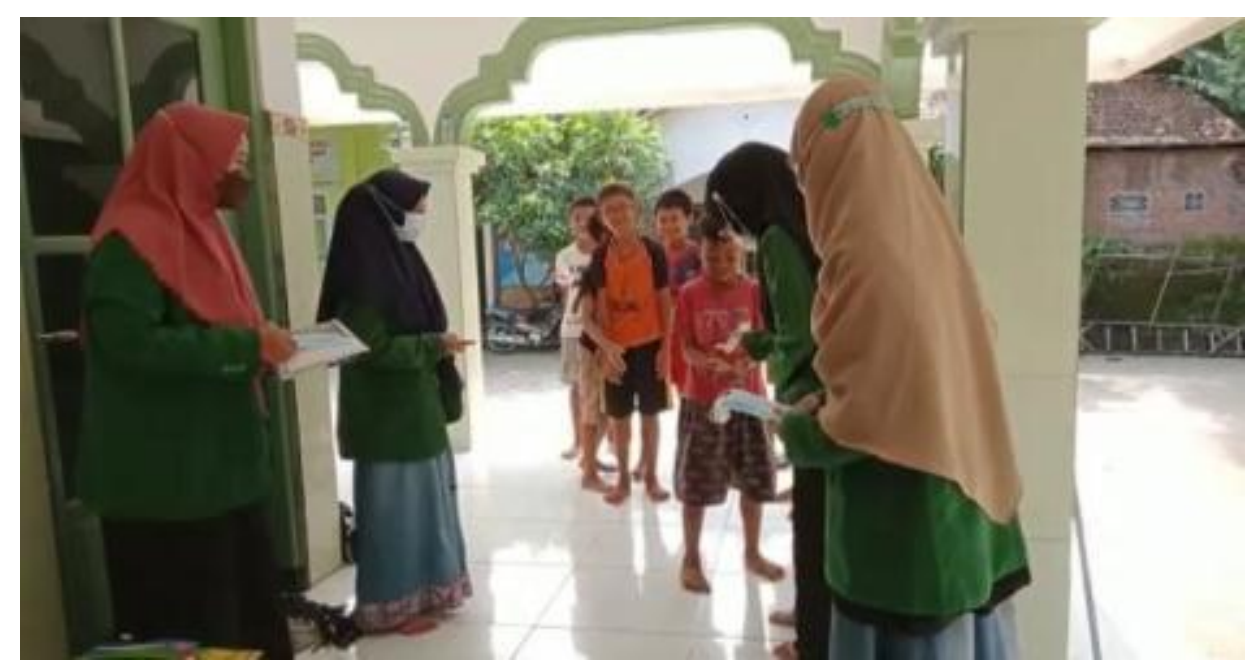

Gambar 2. Sosialisasi pentingnya memakai masker

Kegiatan pemberdayaan selanjutnya yaitu dengan membagikan masker kepada anak-anak SD dan SMP Desa Bulu. Kegiatan pembagian masker dimaksudkan mendorong anak-anak untuk memakai masker ketika beraktivitas di luar rumah, baik ketika bermain dengan teman-temannya ataupun ketika melakukan kegiatan lainnya. 


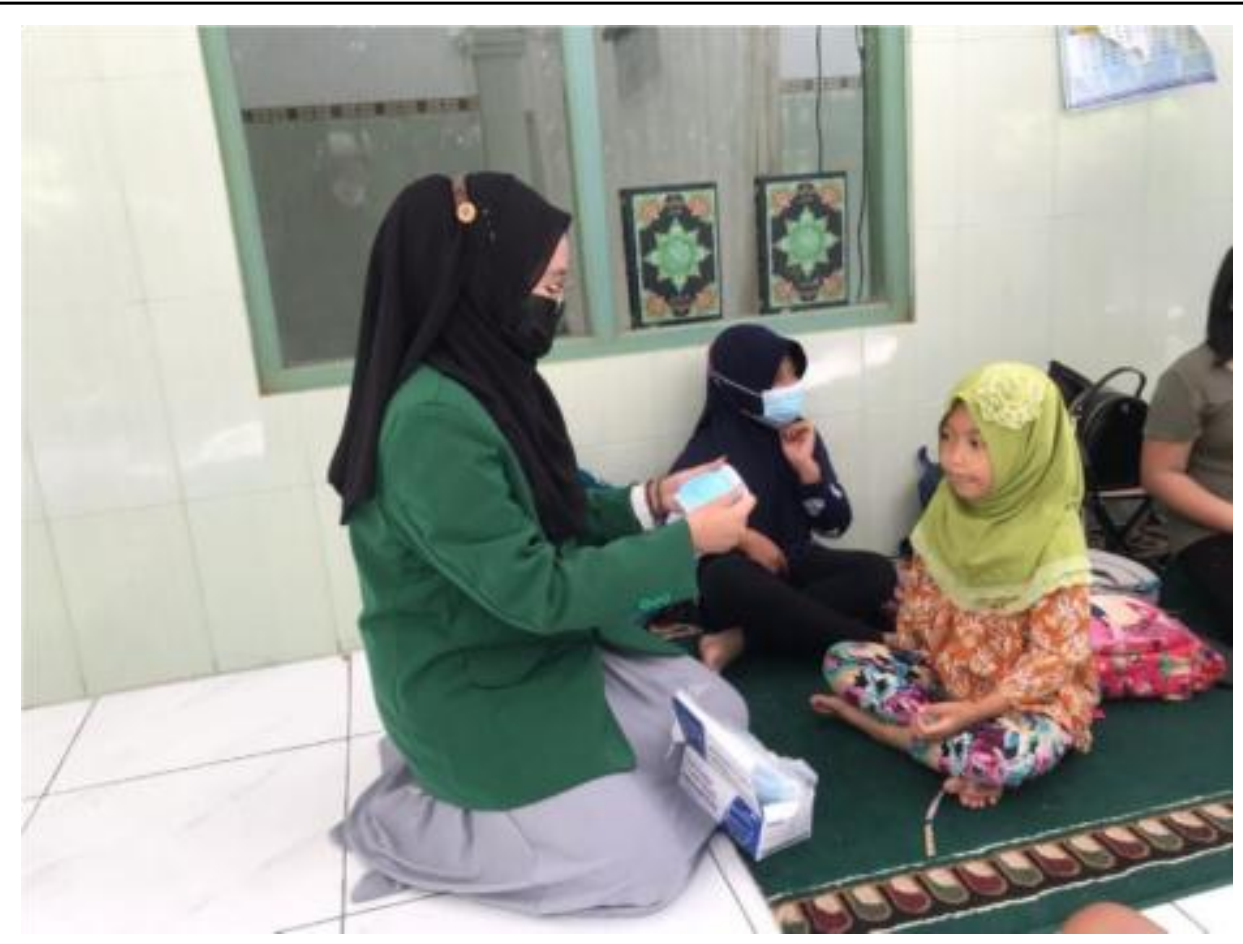

Gambar 3. Pembagian masker

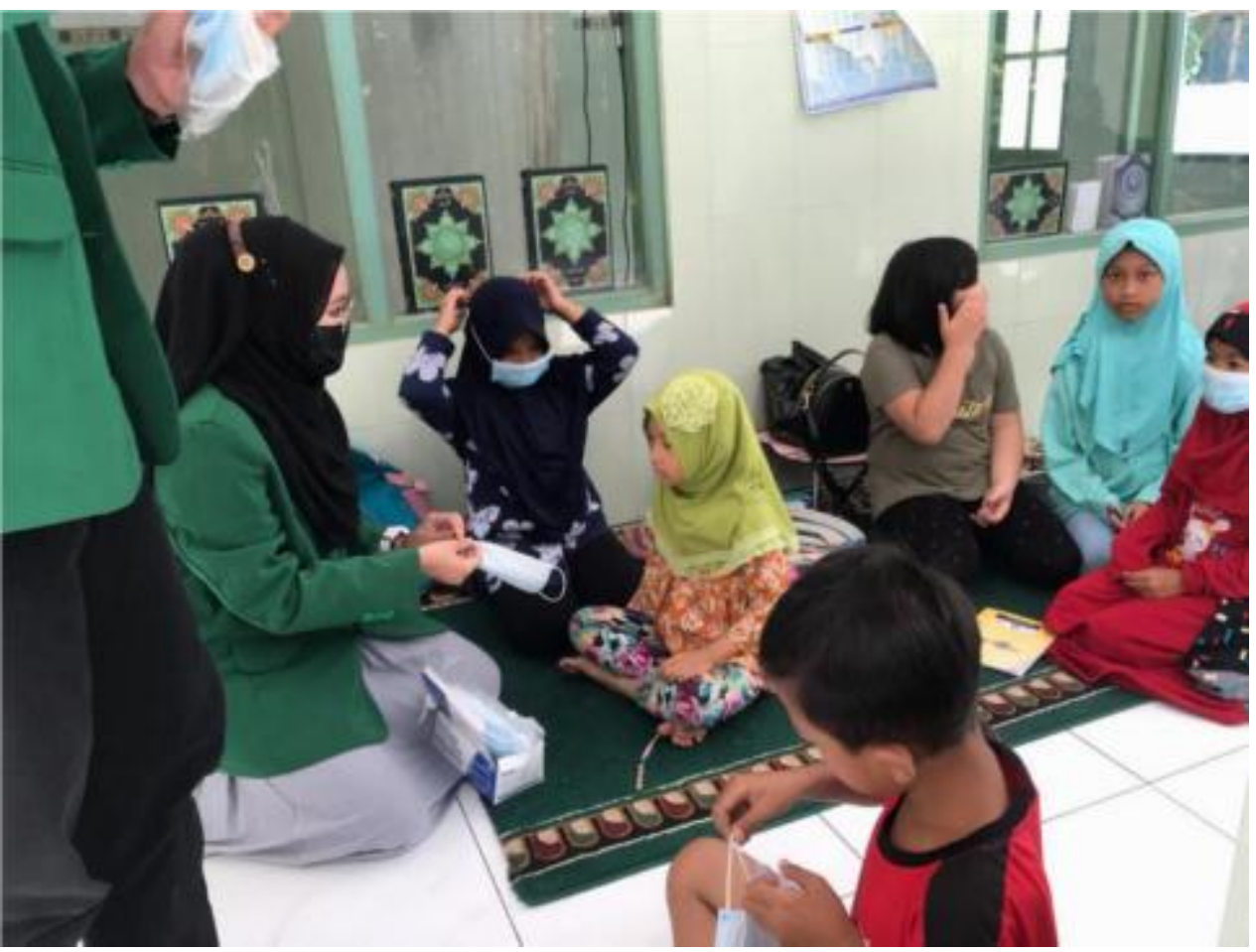

Gambar 4. Edukasi pemakaian masker yang benar

Dari 15 anak yang hadir dalam kegiatan tersebut, sudah lebih dari 60\% yang dapat memakai masker dengan benar sebelum diberikan edukasi. Pentingnya mematuhi protokol kesehatan dari pemerintah untuk mengurangi penularan COVID-19 di masyarakat perlu disosialisasikan termasuk kepada anak-anak Desa Bulu. Kegiatan pemberdayaan dilakukan selama KKN yaitu 6 minggu dengan waktu kurang lebih satu jam dengan materi berbeda tiap kegiatan. Materi yang 
disampaikan yaitu berkaitan dengan 5M (mencuci tangan, memakai masker, menjaga jarak, menjauhi kerumunan dan mengurangi mobilitas). Diharapkan masyarakat khususnya anak-anak dapat aware dengan kesehatan dirinya sendiri dari edukasi yag didapatkan ketika mengikuti kegiatan pemberdayaan ini.

\section{PENUTUP}

Kegiatan pemberdayaan melalui sosialisasi dan edukasi patuh protokol kesehatan yang dilakukan oleh mahasiswa KKN IAIN Kediri berjalan sesuai program kerja yang telah direncanakan. Sasaran kegiatan yaitu berjumlah 15 anak SD dan SMP di Desa Bulu Kecamatan Ngasem Kabupaten Kediri. Kegiatan pemberdayaan dilakukan dengan pemberian edukasi pentingnya menerapkan $5 \mathrm{M}$ setiap melakukan aktivitas di luar rumah. Kemudian diikuti dengan pembagian masker kepada anak-anak. Kegiatan ini dilakukan tiga kali dalam sepekan selama enam minggu KKN berlangsung. Dari kegiatan yang dilaksanakan memberikan dampak positif kepada anak-anak Desa Bulu Kecamatan Semen Kabupaten Kediri. Edukasi yang telah disampaikan oleh mahasiswa KKN IAIN Kediri diharapkan menjadi titik balik berkurangnya kasus pasien positif COVID-19 di Indonesia, khususnya di Desa Bulu itu sendiri.

\section{E. UCAPAN TERIMA KASIH}

Penulis berterimakasih kepada Bapak Moch. Sya'roni selaku pengurus mushola yang telah mengizinkan saya dan tim melakukan pemngabdian melalui pemberdayaan kelompok belajar anak SD dan SMP dengan memberikan edukasi mengenai patuh protokol kesehatan dan rasa terimakasih kepada IAIN Kediri yang telah memberikan kesempatan untuk melaksanakan kegiatan KKN-DR 2021.

\section{F. DAFTAR PUSTAKA}

Embu, W. S. (2021). Data Terbaru Pasien Covid-19 di Wisma Atlet per 29 Agustus 2021. Merdeka.Com. https://www.merdeka.com/peristiwa/data-terbarupasien-covid-19-di-wisma-atlet-per-29-agustus-2021.html

Hikmah, S. F., Jauhariyah, N. A., Aziz, A., Faqih, M., Isnaini, F., \& Pahlevi, M. R. (2021). Optimalisasi Pengolahan Limbah Rumah Tangga MenggunakanMetode Takakura Di Desa Tamansari Sofi. Loyalitas: Jurnal Pengabdian Kepada Masyarakat, IV(2), 171-186.

Napitu, U., Corry, C., \& Matondang, K. D. (2021). Sosialisasi Pembatasan Pelaksanaan Kegiatan Masyarakat (PPKM) Mikro Di Kelurahan Bah Kapul. Community Development Journal : Jurnal Pengabdian Masyarakat, 2(2), 232241. https://doi.org/10.31004/cdj.v2i2.1698

Rosmita, \& Setyorini, D. (2021). Analisa Tren Yang Terkonfirmasi Covid 19 Awal Tahun 2021 Di Indonesia. Jurnal Mitra Manajemen, 4(12), 1599-1606. https://doi.org/10.52160/ejmm.v4i 12.486

Sudiadnyani, N. P., Larasati, A., \& Eksa, D. (2021). Penyuluhan Tentang Pentingnya Pengetahuan Penggunaan Masker dengan Baik dan Benar Pada Anak-Anak. Jurnal Kreativitas Pengabdian Kepada Masyarakat (PKM), 4(3), 535-541.

Sukmana, H. (2021). Implementation of The Policy of The Minister of Health of The Republic of Indonesia Concerning The Health Protocol for The Community in Place and Public Facilities to Press The Spread of Covid-19 in The Sidoario Area. JKMP (Jurnal Kebijakan Dan Manajemen Publik), 9(1), 1-9. https://doi.org/10.21070/jkmp.v9i1.1554 